\title{
SUPERVISI KLINIK DALAM PELAYANAN KEPERAWATAN SEBAGAI UPAYA PENINGKATAN KOMPETENSI PERAWAT DI RUMAH SAKIT
}

\author{
Nur Wahyu Puspitasari ${ }^{1}$, Nurkholis ${ }^{1}$, Febriana Tri Kusumawati ${ }^{1}$, Arif Puji Atmanto ${ }^{1}$, \\ Mohammad Zuhri $^{1}$, Sulistiyaningsih ${ }^{1}$, M. Martono Diel ${ }^{1}$, Yudhanoorsanti Elmonita ${ }^{1}$, \\ Clara Agustina ${ }^{1}$ Meidiana Dwidiyanti ${ }^{2}$ \\ ${ }^{1}$ Mahasiswa Program Studi Magister Keperawatan Fakultas Kedokteran Universitas Diponegoro \\ ${ }^{2}$ Dosen Keperawatan Universitas Diponegoro \\ mdwidiyanti@gmail.com
}

\begin{abstract}
Abstrak
Perawat memiliki berbagai kompetensi yang harus dikuasai dalam memberikan asuhan keperawatan kepada pasien. Kompetensi perawat sangat luas, mencakup praktik profesional, etis, legal, peka budaya, pemberian asuhan, manajemen asuhan keperawatan, pengembangan kualitas personal dan profesional. Supervisi klinik menjadi syarat penting untuk memantau penerapan kompetensi perawat, sehingga dapat tercipta kinerja yang memuaskan. Kinerja perawat yang belum mencapai standar yang telah ditetapkan DEPKES RI, dapat mengakibatkan terjadinya tindakan - tindakan yang tidak sesuai SOP, kurang baiknya dalam pemberian pelayanan keperawatan, sehingga menimbulkan cedera, kerugian, bahkan komplain dari pasien dan masyarakat. Kejadian tersebut dapat menimbulkan penurunan kualitas pelayanan kesehatan dan penurunan tingkat kepercayaan masyarakat terhadap profesi perawat. Oleh karena itu perlu adanya solusi yang tepat untuk mempertahankan kualitas pelayanan. Penelitian ini bertujuan untuk mengetahui pengaruh supervisi klinik terhadap peningkatan kompetensi perawat. Penelitian ini menggunakan metode sistematic review melalui pencairan database, scanning, dan screening 8 artikel dari 90 artikel yang didapat. Hasil penelitian didapatkan adanya perbedaan pelayanan keperawatan, ditunjukkan dari peningkatan kompetensi perawat yang berpengaruh terhadap kinerja perawat. Kinerja perawat dipengaruhi oleh faktor internal yang meliputi kepatuhan dokumentasi keperawatan dan kepatuhan cuci tangan five moment. Sedangkan faktor eksternal meliputi penurunan burnout, peningkatan lingkungan kerja, dan penurunan risiko jatuh. Dari berbagai jurnal menunjukkan bahwa superfisi klinik dapat memberikan dampak positif terhadap kinerja perawat baik secara internal maupu eksternal. Banyaknya dampak positif supervisi klinik di rumah sakit dapat menjadi acuan agar supervisi klinik terus di lakukan di rumah sakit. Adanya supervisi klinik yang dilakukan dengan tepat diharapakan kegiatan asuhan keperawatan dapat terus ditingkankan sesuai kompetensi perawat.
\end{abstract}

Kata kunci: Supervisi klinik, perawat, kompetensi perawat, kinerja perawat

\begin{abstract}
Clinical supervision in nursing services as an efforts to improve nurse competency in hospitals. Nurses have various competencies that must be mastered in providing nursing care to patients. Nurses' competencies are very broad, covering professional, ethical, legal, cultural-sensitive practices, providing care, nursing care management, developing personal and professional qualities. Clinical supervision is an important requirement for monitoring the application of nurse competencies, so that satisfactory performance can be created. The performance of nurses who have not reached the standards set by the RI Ministry of Health, can result in actions that are not in accordance with the SOP, poor in providing nursing services, causing injury, loss, even complaints from patients and the public. These events can lead to a decrease in the quality of health services and a decrease in the level of public trust in the nursing profession. Therefore it is necessary to have the right solution to maintain service quality. This study aims to determine the effect of clinical supervision on improving nurse competency. This research uses sistematic review method through database disbursement, scanning, and screening 8 articles from 90 articles obtained. The results showed that there were differences in nursing services, indicated by an increase in nurses 'competencies which had an effect on nurses' performance. Nurse performance is influenced by internal factors which include compliance with nursing documentation and compliance with five-moment hand washing. While external factors include a decrease in burnout, an increase in the work environment, and a reduced risk of falling. From various journals, it was shown that clinical superfissions can have a positive impact on the performance of nurses both internally and externally. The many positive effects of clinical supervision in hospitals can be a reference for clinical supervision to
\end{abstract}


continue at the hospital. The existence of clinical supervision carried out appropriately is expected that nursing care activities can continue to be increased according to nurses' competencies.

Keywords: Clinical supervision, nurses, nurse competencies, nurse performance

\section{Pendahuluan}

Keperawatan merupakan bentuk pelayanan profesional yang di dasarkan pada ilmu keperawatan. Pada perkembangannya ilmu keperawatan selalu mengikuti perkembangan ilmu lain, mengingat ilmu keperawatan merupakan ilmu terapan yang selalu berubah mengikuti perkembangan zaman. Demikian juga dengan pelayanan keperawatan di indonesia, harus mampu memberikan pelayanan kepada masyarakat secara profesional sesuai dengan tuntutan zaman dan kompetensinya (Lestari, 2014).

Perawat memiliki berbagai kompetensi yang harus dikuasai dalam memberikan asuhan keperawatan kepada pasien. Kompetensi perawat sangat luas, mencakup praktik profesional, etis, legal, peka budaya, pemberian asuhan, manajemen asuhan keperawatan, pengembangan kualitas personal dan profesional. Dalam praktik profesional, perawat perlu memperhatikan segala hal yaitu kepatuhan cuci tangan, memonitoring risiko jatuh, beban kerja/ burn out, hingga hal yang tidak kalah penting yaitu dokumentasi. Dokumentasi keperawatan merupakan hal krusial sebagai bukti dan pertanggungjawaban atas tindakan keperawatan. Setiap detail tindakan keperawatan harus dilakukan dengan baik dan benar penuh dengan tanggung jawab sesuai dengan kompetensi masing masing perawat (Ponco, 2016).

Kompetensi tindakan keperawatan yang telah berjalan selama ini masih jauh dari harapan dan tujuan pemerintah. Berdasarkan hasil penelitian di rumah sakit tingkat 2 putri hijau medan tahun 2015 menunjukkan bahwa kinerja perawat belum mencapai target yakni sebanyak $71 \%$ memberi asuhan keperawatan, padahal menurut DEPKES RI standar pencapaian kinerja dalam pemberian asuhan keperawatan minimal $75 \%$ (Siahaan, 2012).

Kinerja perawat yang buruk atau belum mencapai standar yang telah ditetapkan DEPKES RI, dapat mengakibatkan terjadinya tindakan tindakan yang tidak sesuai SOP, kurang baiknya dalam pemberian pelayanan keperawatan, sehingga menimbulkan cedera, kerugian, bahkan komplain dari pasien dan masyarakat. Terjadinya hal ini pada sebuah institusi pelayanan kesehatan, akan menimbulkan penurunan kualitas pelayanan kesehatan dan menurunnya tingkat kepercayaan masyarakat terhadap profesi perawat (Yanti, 2013).

Perawat perlu mulai berbenah untuk mengurangi dampak yang diakibatkan oleh kurang baiknya kinerja dan kompetensi perawat, salah satunya dengan melakukan supervisi klinik. Supervisi klinik berorientasi pada masalah klinik pasien dan dilaksanakan oleh kepala ruang kepada ketua tim dan ketua tim kepada perawat pelaksana. Pelaksanaan supervisi klinik misalnya tentang pelaksanaan dokumentasi asuhan keperawatan, interaksi perawat kepada pasien, dan pelaksanaan program kolaborasi dengan tim kesehatan. Supervisi klinik menjadi prasyarat penting dalam melakukan asuhan keperawatan yang bermutu.

\section{Metode}

Design review disajikan dalam bentuk sistematik review terhadap beberapa literatur, dimana pencarian literatur dilakukan secara komprehensif terhadap clinical and academic research dari beberapa database untuk mendapatkan evidence yang relevan. Pencairan database, scanning, dan screening artikel dilakukan secara mandiri oleh kelompok. kelompok mengikuti syarat dalam pemenuhan kriteria inklusi pada artikel. Kriteria inklusi dengan memilih artikel dari hasil penelitian 
kuantitatf dengan desain Randomized Control Trial atau Control Trial, cohort dan case control. Intervensi dilakukan di rumah sakit dan dilakukan pada profesi perawat. Intervensi yang dilakukan adalah memberikan atau meningkatkan tindakan supervisi klinik yang memberikan Outcome baik terhadap kegiatan di rumah sakit maupun sumber daya manusia di rumah sakit. Kriteria eksklusi digunakan untuk menfokuskan pada hasil review terbaik, tidak diambil artikel yang berisi supervisi di ranah pendidikan, atau yang dilakukan pada siswa perawat maupun pada profesi selain perawat.

Strategi pencarian literature untuk mendapatkan artikel terbaik guna mendukung evidence, pencarian literature dibatasi untuk literatur 6 tahun terakhir (2013-2018), berbahasa Inggris dan Indonesia dan diidentifikasi menggunakan database elekronik internasional dari, Proquest, Sciencedirect, Oxford, Caul, Chocraine, Springerlink, Cambridge, Ners Media, Emerald, BMC nursing, Libgen, database elektronik nasional. Dengan menggunakan kata kunci clinical supervision dan method, nursing, nurse, maka pencarian awal melalui index tersebut, didapatkan 90 artikel. Artikel difilter sesuai dengan kriteria inklusi yang diinginkan, 80 artikel tidak termasuk dalam inklusi. Dari 10 artikel yang sesuai dengan kriteria inklusi, hanya 8 artikel yang akan direview karena 2 artikel abstrak dan tidak memberikan informasi yang lengkap tentang outcome supervise. Strategi pencarian artikel digambarkan pada alur diagram 1. Metode Pengkajian kualitas studi menggunakan tools CASP (Critical Appraisal Skill Program) yang bertujuan untuk menilai kualitasnya berdasarkan hasil kajian dari tools dan level Evidence artikel tersebut. Level Evidence yang digunakan berdasarkan National Institute For Clinical Excellence (NICE). Ekstraksi data dilakukan oleh kelompok. Untuk memudahkan ekstraksi terhadap artikel yang akan direview ditampilkan dalam bentuk tabel dengan format yang sesuai dengan pertanyaan klinik yang telah ditentukan dengan metode PICO yang meliputi, design/method, sample dan setting, intervention, compare, measurement, outcome (finding), appraisal worth to practice dan level evidence.

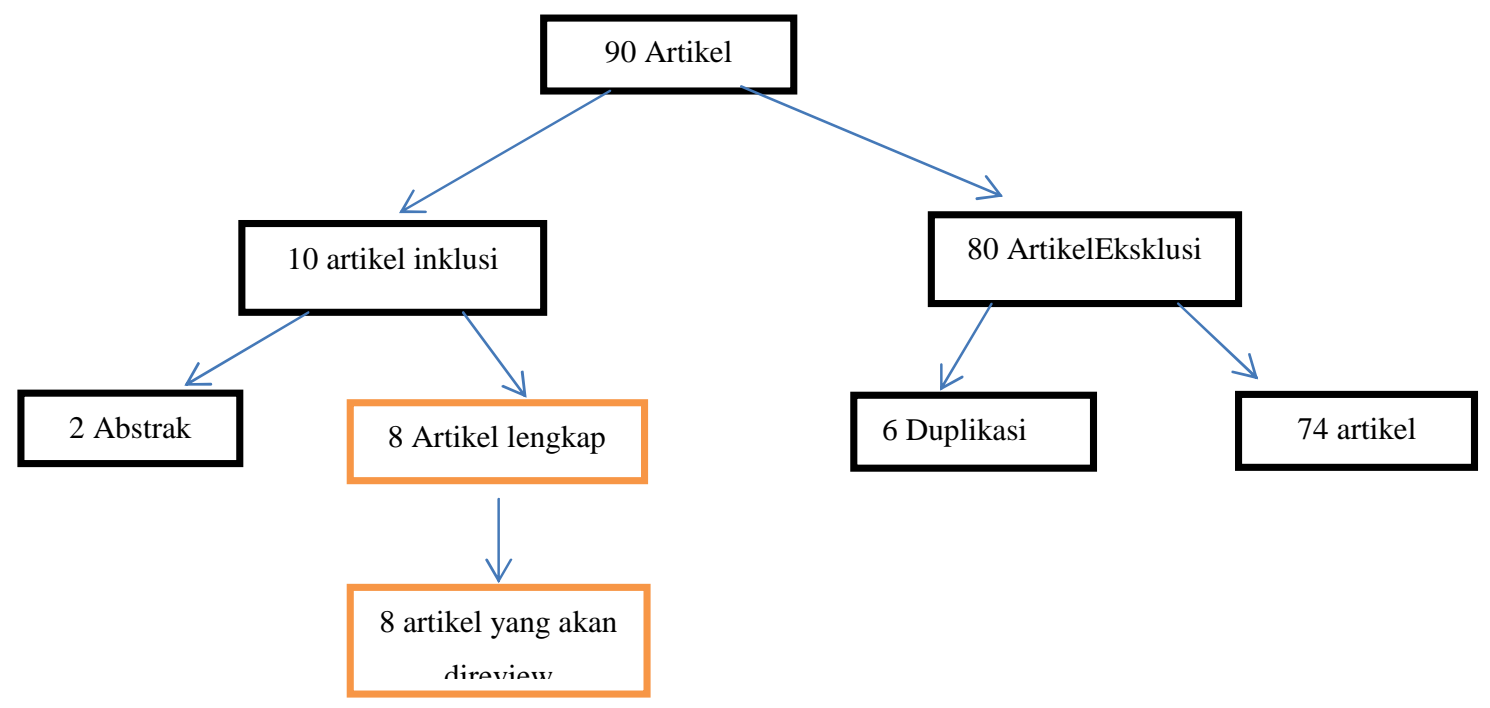

Gambar 1.Diagram Alur: Strategi pencarian Artikel/jurnal yang direview

\section{Hasil}

Pada artikel ini dari 90 artikel jurnal yang didapatkan, kemudian dipilih sesuai kriteria inklusi yakni jurnal yang menggunakan metode kuantitatif dengan desain RCT, case control, quasi 
eksperimen, cross oberservation. Sehingga diapatkan sejumlah 8 jurnal yang dianalisa.
Berikut jabaran dari 8 artikel jurnal yang didapatkan:

Tabel 1

Hasil review 8 artikel jurnal

\begin{tabular}{|c|c|c|c|c|c|c|c|}
\hline No & \multicolumn{2}{|c|}{$\begin{array}{c}\text { Autthor, Tahun, } \\
\text { Vol, Page }\end{array}$} & $\begin{array}{l}\text { Judul/Kategori } \\
\text { judul }\end{array}$ & Instrumen & $\begin{array}{l}\text { Populasi/ } \\
\text { sampel }\end{array}$ & Intervensi & Outcame \\
\hline 1. & $\begin{array}{l}\text { Nunik } \\
\text { Lestari, } \\
\text { Suprapti, } \\
\text { Solecha } \\
2014\end{array}$ & $\begin{array}{r}\text { Wahyu } \\
\text { Erni } \\
\text { Achmad }\end{array}$ & $\begin{array}{l}\text { Pengaruh } \\
\text { Supervisi } \\
\text { Metode Klinik } \\
\text { Terhadap } \\
\text { Kelengkapan } \\
\text { Dokumentasi } \\
\text { Asuhan } \\
\text { Keperawatan } \\
\text { di RSUD . H } \\
\text { Soewondo } \\
\text { Kendal }\end{array}$ & $\begin{array}{l}\text { lembar } \\
\text { observasi } \\
\text { checklist } \\
\text { dokumentasi } \\
\text { asuhan } \\
\text { keperawatan }\end{array}$ & $\begin{array}{l}\text { Populasi : } \\
\text { semua perawat } \\
\text { yang bekerja } \\
\text { di ruang } \\
\text { Flamboyan } \\
\text { dan Kenanga. } \\
\text { sampel : } \\
\text { perawat } \\
\text { bangsal } \\
\text { penyakit } \\
\text { dalam Ruang } \\
\text { Flamboyan } \\
\text { dan Ruang } \\
\text { Kenanga } \\
\text { RSUD Dr. H. } \\
\text { Soewondo } \\
\text { Kendal (35 } \\
\text { responden) }\end{array}$ & $\begin{array}{l}\text { Dilakukan } \\
\text { supervisi metode } \\
\text { klinik pada } \\
\text { kelengkapan } \\
\text { dokumentasi } \\
\text { Asuhan } \\
\text { Keperawatan }\end{array}$ & $\begin{array}{l}\text { Kelengkapan } \\
\text { dokumentasi } \\
\text { asuhan } \\
\text { keperawatan } \\
\text { semakin baik } \\
\text { dan lengkap, } \\
\text { kelengkapan } \\
\text { dokumentasi } \\
\text { dimasing bagian } \\
\text { menunjukan } \\
\text { peningkatan }\end{array}$ \\
\hline 2. & $\begin{array}{l}\text { Dewi } \\
\text { Mustikani } \\
\text { Jurnal } \\
\text { Keperawat } \\
\text { Aisyiyah ( } \\
\text { Volume 1 } \\
\text { 1, Juni 20 }\end{array}$ & $\begin{array}{l}\text { gsih } \\
\text { an } \\
\text { KA) } \\
\text { Nomor }\end{array}$ & $\begin{array}{l}\text { Pengaruh } \\
\text { Supervisi } \\
\text { Klinik Ketua } \\
\text { tim model } 4 \mathrm{~S} \\
\text { terhadap } \\
\text { kinerja } \\
\text { perawat } \\
\text { pelaksana } \\
\text { dalam metode } \\
\text { asuhan } \\
\text { keperawatan } \\
\text { Tim }\end{array}$ & $\begin{array}{l}\text { Observasi, } \\
\text { cross } \\
\text { observation } \\
\text { oleh } \\
\text { peer } \\
\text { assessment } \\
\text { menjadi } \\
\text { range } \\
\text { observasi } \\
\text {. }\end{array}$ & $\begin{array}{l}\text { Populasi: } \\
\text { semua perawat } \\
\text { pelaksana } \\
\text { yang bekerja } \\
\text { di ruang rawat } \\
\text { inap } \\
\text { Rumah Sakit } \\
\text { Muhammadiy } \\
\text { ah Bandung ( } \\
\text { 105 orang) } \\
\text { dan semua } \\
\text { perawat } \\
\text { pelaksana } \\
\text { yang bekerja } \\
\text { di ruang rawat } \\
\text { inap } \\
\text { Rumah Sakit } \\
\text { Al-Islam } \\
\text { Bandung (152 } \\
\text { orang) } \\
\text { Rasio sample } \\
\text { size untuk } \\
\text { kedua } \\
\text { kelompok = } \\
1: 1 \text { besar } \\
\text { sampel } \\
\text { penelitian } \\
\text { tiap kelompok } \\
\text { adalah } 39\end{array}$ & $\begin{array}{l}\text { Kinerja perawat } \\
\text { pelaksana diukur } \\
\text { sebelum ketua tim } \\
\text { mendapat } \\
\text { pelatihan dan } \\
\text { bimbingan } \\
\text { supervisi klinik } \\
\text { model } \\
\text { 4S dan sesudah } \\
\text { sebagai efek dari } \\
\text { pelatihan dan } \\
\text { bimbingan } \\
\text { supervisi klinik } \\
\text { tersebut. } \\
\text { Responden di atas } \\
\text { dibagi ke dalam } \\
\text { dua kelompok, } \\
\text { yaitu praktik } \\
\text { kolaborasi dan } \\
\text { pengembangan } \\
\text { profesi asuhan } \\
\text { metoda a andan tim. } \\
\text { keperawatan }\end{array}$ & $\begin{array}{l}\text { Ada perbedaan } \\
\text { kinerja perawat } \\
\text { pelaksana } \\
\text { dalam metoda } \\
\text { asuhan } \\
\text { keperawatan tim } \\
\text { sebelum dan } \\
\text { sesudah } \\
\text { mendapat } \\
\text { supervisi } \\
\text { klinik dari ketua } \\
\text { tim yang dilatih } \\
\text { dan } \\
\text { dibimbing } \\
\text { supervisi klinik } \\
\text { model 4S pada } \\
\text { kelompok } \\
\text { intervensi }\end{array}$ \\
\hline 3. & $\begin{array}{l}\text { Naglaa } \\
\text { shawadfy } \\
2 \text { Wafaa } \\
\text { Sleem, } \\
\text { Mahmoud }\end{array}$ & $\begin{array}{r}\text { EL- } \\
\text { Saleh, } \\
\text { Fathi } \\
\text { 3Ahlam } \\
\text { EL- }\end{array}$ & $\begin{array}{l}\text { Effect of } \\
\text { Clinical } \\
\text { Supervision } \\
\text { Program for } \\
\text { Head Nurses }\end{array}$ & $\begin{array}{l}\text { - } \quad \text { clinical } \\
\text { supervisio } \\
\text { n } \\
\text { knowledge }\end{array}$ & $\begin{array}{l}\text { Seluruh kepala } \\
\text { ruang perawat } \\
\text { ( } 69 \text { orang) dan } \\
\text { sataff perawat } \\
\text { yang bekerja }\end{array}$ & \begin{tabular}{lr}
\multicolumn{2}{c}{ Data dikumpulkan } \\
dari 2 & kelompok \\
yakni & kelompok \\
kepala & perawat \\
dan & kelompok
\end{tabular} & $\begin{array}{l}\text { Terdapat } \\
\text { peningkatan } \\
\text { yang signifikan } \\
\text { pengetahuan } \\
\text { perawat }\end{array}$ \\
\hline
\end{tabular}




\begin{tabular}{|c|c|c|c|c|c|c|}
\hline & $\begin{array}{l}\text { Shaer, Volume 4, } \\
\text { Issue } 6 \text { Ver. } \quad \text { V } \\
\text { (Nov. - Dec. 2015), }\end{array}$ & $\begin{array}{l}\text { on Quality } \\
\text { Nursing Care }\end{array}$ & $\begin{array}{l}\text { questionna } \\
\text { ire, } \\
\text { - } \\
\text { Mancheste } \\
\text { r Clinical } \\
\text { Supervisio } \\
\text { n Scale } \\
\text { and } \\
\text { - Quality of } \\
\text { Nursing } \\
\text { Care } \\
\text { observatio } \\
\text { n sheet }\end{array}$ & $\begin{array}{ll}\text { di Kafer El- } \\
\text { Sheikh } \\
\text { General } \\
\text { Hospital. }\end{array}$ & & $\begin{array}{l}\text { berkaitan } \\
\text { dengan } \\
\text { supervisi klinik. }\end{array}$ \\
\hline 4 & $\begin{array}{l}\text { Bev O'Connell, } \\
\text { Cherene M. } \\
\text { Ockerby, Susan } \\
\text { Johnson, Helen } \\
\text { Smenda, } \\
\text { Tracey and } \\
\text { Bucknall, } 2015\end{array}$ & $\begin{array}{l}\text { Team Clinical } \\
\text { Supervision in } \\
\text { Acute } \\
\text { Hospital } \\
\text { Wards: } \\
\text { A Feasibility } \\
\text { Study }\end{array}$ & $\begin{array}{l}\text { Work } \\
\text { Environment } \\
\text { Questionnair } \\
\text { e (WEQ; } \\
\text { Severinsson } \\
\text { \& Kamaker, } \\
\text { 1999) }\end{array}$ & $\begin{array}{lr}36 & \text { Staf } \\
\text { perawat } & \text { dan } \\
\text { bidan di } & \text { dua } \\
\text { bangsal } & \text { di } \\
\text { rumah sakit } \\
\text { swastadi } \\
\text { Melbourne } \\
\text { Australia } \\
\text { berumur } 21-25 \\
\text { tahun }\end{array}$ & $\begin{array}{l}\text { Kuisioner WEQ } \\
\text { diisi oleh } \\
\text { partisipan, setelah } \\
\text { itu diadakan fokus } \\
\text { grup untuk } \\
\text { memberikan } \\
\text { perspektif } \\
\text { kualitatif tentang } \\
\text { penerimaan Team } \\
\text { Supervisi klinik }\end{array}$ & $\begin{array}{l}\text { Tim Supervisi } \\
\text { klinik dapat } \\
\text { merupakan } \\
\text { strategi untuk } \\
\text { meningkatkan } \\
\text { lingkungan } \\
\text { kerja yang lebih } \\
\text { sehat dengan } \\
\text { hasil yang } \\
\text { positif bagi staf } \\
\text { individu, tim } \\
\text { bangsal, pasien } \\
\text { dan organisasi } \\
\text { pelayanan } \\
\text { kesehatan }\end{array}$ \\
\hline 5 & \begin{tabular}{l}
\multicolumn{3}{l}{ Sri Hananto Ponco, } \\
Virgianti $\quad$ Nur \\
Faridah, 2016
\end{tabular} & $\begin{array}{l}\text { penerapan } \\
\text { supervisi } \\
\text { klinik kepala } \\
\text { ruang untuk } \\
\text { meningkatkan } \\
\text { pelaksanaan } \\
\text { cuci tangan } \\
\text { lima momen } \\
\text { perawat } \\
\text { pelaksana } \\
\text { RSUD } \\
\text { Bojonegoro }\end{array}$ & kuesioner & $\begin{array}{l}\text { Sampel adalah } \\
42 \text { perawat } \\
\text { pelaksana } \\
\text { RSUD } \\
\text { Bojonegoro }\end{array}$ & \begin{tabular}{lr}
\multicolumn{2}{l}{ Supervisi klinik di } \\
6 ruang rawat \\
inap \\
Kepala ruang \\
diberikan \\
pelatihan \\
supervisi klinik. \\
Data diambil \\
sebelum diberikan \\
pelatihan \\
supervisi klinik \\
dan \\
diberikan \\
pelatihan.
\end{tabular} & $\begin{array}{l}\text { Pelaksanaan } \\
\text { supervisi klinik } \\
\text { akan } \\
\text { meningkatkan } \\
\text { pelaksanaan } \\
\text { cuci tangan lima } \\
\text { momen Rumah } \\
\text { Sakit di } \\
\text { Bojonegoro } \\
(\mathrm{p}=0.000, \\
\mathrm{p}<0.05) .\end{array}$ \\
\hline 6 & $\begin{array}{l}\begin{array}{l}\text { Sandra Cruz, Luís } \\
\text { Carvalho, } \\
\text { Lopes }\end{array} \\
2016 \\
\text { Volsa } 217 \\
\text { p. } 382-388\end{array}$ & $\begin{array}{l}\text { Improving the } \\
\text { evaluation of } \\
\text { risk of fall } \\
\text { through } \\
\text { clinical } \\
\text { supervision: } \\
\text { an evidence } \\
\text { Procedia - } \\
\text { Social and } \\
\text { Behavioral } \\
\text { Sciences }\end{array}$ & $\begin{array}{l}\text { Pengkajian } \\
\text { dan } \\
\text { monitoring } \\
\text { resiko jatuh } \\
\text { dengan } \\
\text { Morse Fall } \\
\text { Scale }^{\circledR} \\
\text { (MFS) } \\
\text { Pelaksanaan } \\
\text { model } \\
\text { supervisi } \\
\text { klinik }\end{array}$ & $\begin{array}{l}132 \text { pasien } \\
\text { yang dirawat } \\
\text { antara tanggal } \\
\text { 19 Maret s/d } \\
\text { 19 Mei 2014 } \\
\text { Criteria } \\
\text { inklusi: pasien } \\
\text { dirawat lebih } \\
\text { dari 24 jam, } \\
\text { bukan pasien } \\
\text { yang pernah } \\
\text { dirawat } \\
\text { sebelumnya }\end{array}$ & $\begin{array}{l}\text { Pelaksanaan } \\
\text { model supervisi } \\
\text { klinik dengan } \\
\text { melakukan } \\
\text { observasi } \\
\text { terhadap } \\
\text { pengkajian resiko } \\
\text { jatuh } \\
\text { menggunakan } \\
\text { MFS yang } \\
\text { dimonitor dan } \\
\text { didokumentasikan } \\
\text { dalam catatan } \\
\text { keperawatan }\end{array}$ & $\begin{array}{l}\text { - Perawat } \\
\text { menerapkan } \\
\text { MFS dengan } \\
\text { benar } 69,2 \% \\
\text { - Resiko jatuh } \\
\text { dimonitor 48jam } \\
\text { dalam 98,5\% } \\
\text { kasus dengan } \\
\text { MFS } \\
\text { - terjadi } \\
\text { peningkatan } \\
\text { dalam } \\
\text { pengkajian dan } \\
\text { monitoring } \\
\text { resiko jatuh } \\
\text { dengan MFS } \\
\text { dan } \\
\text { berhubungan }\end{array}$ \\
\hline
\end{tabular}




\begin{tabular}{|c|c|c|c|c|c|c|}
\hline & & & & & & $\begin{array}{l}\text { dengan } \\
\text { pelaksanaan } \\
\text { model supervisi } \\
\text { klinik } \\
\text { - setelah } \\
\text { pelaksanaan } \\
\text { model supervisi } \\
\text { klinik pada } \\
\text { perawat, ada } \\
\text { banyak } \\
\text { intervensi } \\
\text { keperawatan } \\
\text { yang cocok } \\
\text { untuk } \\
\text { mengidenfikasi } \\
\text { rersiko jatuh }\end{array}$ \\
\hline 7 & $\begin{array}{lr}\text { Kristaps } & \text { Circenis, } \\
\text { Jekaterina } & \\
\text { Jeremejeca, } & \text { Inga } \\
\text { Millere, } & \text { Liana } \\
\text { Deklaca, } & \text { Artuts } \\
\text { Paparde, } & \text { Velga } \\
\text { Sudraba } & \\
2015.2015 .86-91\end{array}$ & $\begin{array}{l}\text { Supervision in } \\
\text { Nursing L } \\
\text { Latvian } \\
\text { Sample Study. }\end{array}$ & $\begin{array}{l}\text { MBI } \\
\text { (Maslach } \\
\text { Burnout } \\
\text { Inventory) } \\
\text { dengan } \\
\text { pengukutan } \\
\text { emotional } \\
\text { exhaustion, } \\
\text { depersionalis } \\
\text { ation, dan } \\
\text { personal } \\
\text { accomplish } \\
\text { ment. }\end{array}$ & $\begin{array}{l}\text { Individual } \\
\text { supervision } 30 \\
\text { orang, control } \\
\text { group : } 30 \\
\text { orang } \\
\text { Perawat } \\
\text { mental health } \\
\text { yang } \\
\text { teregistrasi }\end{array}$ & $\begin{array}{l}\text { Pengukuran } \\
\text { dilakukan } \\
\text { sebelum dan } \\
\text { setelah supervisi. } \\
\text { Menggunakan } \\
\text { human services } \\
\text { surveyvariant } \\
\text { yang ditranslate di } \\
\text { Ltvian. Ssetiap } \\
\text { partisipan mengisi } \\
\text { kuesioner survey } \\
\text { dan kepuasan } \\
\text { setelah mengikuti } \\
\text { supervisi. }\end{array}$ & $\begin{array}{l}\text { Supervisi } \\
\text { menurunkan } \\
\text { burnout, } \\
\text { membantu } \\
\text { perawat } \\
\text { memahami } \\
\text { dirinya dengan } \\
\text { baik, emosi, dan } \\
\text { aspek kebiasaan }\end{array}$ \\
\hline 8 & $\begin{array}{l}\text { Asghar } \\
\text { Khalifehzadeh } \\
\text { Esfahani } \\
\text {, Fatemeh } \\
\text { Vamezany } \\
\text { Varzaneh } \\
\text {, Tahereh Changiz } \\
\text { 2016, 482-486 }\end{array}$ & $\begin{array}{l}\text { The effect of } \\
\text { clinical } \\
\text { supervision } \\
\text { model on high } \\
\text { alert } \\
\text { medication } \\
\text { safety in } \\
\text { intensive care } \\
\text { units nurses } \\
\text { journal of } \\
\text { nursing and } \\
\text { midwifery } \\
\text { research }\end{array}$ & $\begin{array}{l}\text { Observasi } \\
\text { dan } \\
\text { kuesioner } \\
\text { karakteristik } \\
\text { demografi } \\
\text { dan } 5 \text { daftar } \\
\text { periksa dari } \\
\text { "program } \\
\text { instruksi } \\
\text { keselamatan } \\
\text { obat berisiko } \\
\text { tinggi" }\end{array}$ & $\begin{array}{lr}32 \text { responden } \\
\text { terdiri atas } & 12 \\
\text { perawat } & \text { di } \\
\text { ICU, } & 13 \\
\text { perawat } & \text { di } \\
\text { ICU II, } & 4 \\
\text { perawat di } \\
\text { ICU III dan } 3 \\
\text { PERAWAT } \\
\text { DI CCU RS } \\
\text { Al Zahra }\end{array}$ & $\begin{array}{l}\text { Tahap intervensi, } \\
\text { peneliti } \\
\text { menghadiri } \\
\text { bangsal, dan } \\
\text { setiap subjek } \\
\text { memberikan obat } \\
\text { dan daftar periksa } \\
\text { dicentang. Daftar } \\
\text { periksa ini dibuat } \\
\text { dengan konsensus } \\
\text { antara peneliti } \\
\text { sebagai supervisor } \\
\text { dan perawat } \\
\text { sebagai yang } \\
\text { diawasi. Setelah } \\
\text { intervensi, } \\
\text { peneliti } \\
\text { mengevaluasi }\end{array}$ & $\begin{array}{l}\text { Model supervisi } \\
\text { keperawatan } \\
\text { klinik dapat } \\
\text { diterapkan } \\
\text { sebagai sistem } \\
\text { terorganisir } \\
\text { untuk } \\
\text { meningkatkan } \\
\text { fungsi perawat } \\
\text { dalam } \\
\text { mengurangi } \\
\text { kesalahan } \\
\text { pengobatan dan } \\
\text { kejadian buruk } \\
\text { dalam pemberian obat } \\
\text { berisiko tinggi } \\
\text { (ICU) }\end{array}$ \\
\hline
\end{tabular}

\section{Pembahasan}

Supervisi klinik meningkatkan kepercayaan dan hubungan dengan supervisor, dan kemampuan mendiskusikan masalah sensitif yang terjadi di tempat kerja. Cross, Moore, dan Ockerby menyatakan supervisi klinik dapat diimplementasikan dalam lingkungan yang sibuk dengan sumber daya manusia minimal (Cross, 2010). Hasil analisis penelitian yang dilakukan oleh Lucia tahun 2004 di Rumah Sakit Elizabeth Semarang menunjukkan bahwa sesudah penerapan supervisi klinik terdapat peningkatan kompetensi secara bermakna dengan (p.value 0.000), score rata - rata sebelum supervisi klinik (6.88) menjadi (13.02) (Lucia, 2004). 
Berdasarkan penelitian yang dilakukan oleh Asghar dalam jurnalnya yang berjudul The Effect of Clinical Supervision Model on High Alert Medication Safety in Intencive Care Units Nurses menunjukkan adanya perbedaan yang signifikan pada nilai rata - rata pemberian pengobatan menggunakan obat - obatan resiko tinggi (heparin, warfarin, norepinephrine, dobutamin, dan dopamin) sebelum dan sesudah dilakukan supervisi klinik. Penelitian tersebut menyimpulkan bahwa pelaksanaan supervisi klinik di ruang Intensive Care Unit dapat meningkatkan status keselamatan dan keamanan penggunaan obat - obatan resiko tinggi (high alert medication) (Esfahani, 2017).

1. Kinerja keperawatan

Kinerja merupakan hasil atau fungsi kegiatan individu ataupun kelompok di sebuah organisasi yang dapat dipengaruhi oleh berbagai faktor untuk mencapai tujuan yang diinginkan (Pabundu, 2006). Pada jurnal penelitian yang dilakukan oleh Mustikaningsih, didapatkan bahwa terdapat pengaruh supervisi klinik model $4 \mathrm{~S}$ terhadap kinerja perawat di rumah sakit. Sejalan dengan penelitian yang dilakukan oleh Zahara, Sitorus dan Sabri (2011) yang menjelaskan bahwa terdapat hubungan yang signifikan antara supervisi klinik dengan motivasi kerja perawat. Melalui motivasi kerja yang tinggi maka secara langsung akan meningkatkan kerja perawat. Mandagi, Umboh, dan Ratu (2015) juga menjelaskan bahwa terdapat beberapa faktor yang mempengaruhi kinerja perawat diantaranya motivasi, supervisi, dan penghargaan. Supervisi memiliki peranan penting dari manajemen keperawatan. Kondisi tersebut dikarenakan melalui supervisi dapat mengatasi masalah yang ada di dalam organisasi dengan cepat. Peran supervisi sangat erat dengan fungsi kepemimpinan. Pemimpin atau supervisor dapat dianggap sebagai figur ayah di mana dapat mengawasi, mengarahkan dan menampung segala keluhan berkaitan pekerjaan meupun masalah pribadi yang dapat menghambat kinerja perawat. Hasil yang didapatkan bahwa melalui supervisi mampu menjadi motivasi bagi diri sendiri. Supervisi juga melatih emosi, mengajarkan perawat untuk memberi performance yang terbaik.Pabundu (2006) juga menjelaskan bahwa terdapat beberapa faktor yang dapat mempengaruhi kinerja karyawan yakni :

a. Faktor internal

Faktor internal adalah suatu hal yang berhubungan dengan kecerdasan, keterampilan, kestabilan emosi, emosi serta sifat individu( sikap, kepribadian, fisik, keinginan, motivasi, umur, jenis kelamin, pendidikan, pengalaman kerja, latar belakang dan budaya dan lain sebagainya).

1) Meningkatkan kepatuhan pelaksanaan dokumentasi keperawatan

Berdasarkan hasil penelitian sebelum dilakukan supervisi metode klinik didapatkan $26 \quad(74,3 \%)$ dokumentasi asuhan keperawatan dalam kategori kurang lengkap. Alasan perawat jarang untuk melengkapi dokumentasi asuhan keperawatan salah satu faktornya karena kurangnya pengawasan, pengontrolan terhadap dokumentasi asuhan keperawatan. Setelah 3 hari dilakukan supervisi metode klinik terjadi peningkatan dari $26(74,3 \%)$ dokumentasi asuhan keperawatan tidak lengkap menjadi $25(71,4 \%)$ dokumentasi asuhan keperawatan dalam kategori lengkap. Didapatkan $87,20 \%$ perawat menuliskan dokumentasi pengkajian secara lengkap, 59,45\% dokumentasi diagnosa dan intervensi dituliskan secara lengkap, 94,28\% dokumentasi implementasi dituliskan secara lengkap dan $87,5 \%$ dokumentasi evaluasi dituliskan secara lengkap (Lestari, Wahyu, Suprapti, Solechan. 2014).

Supervisi yang dilakukan pada saat perawat pelaksana menuliskan atau mengisi dokumentasi sehingga supervisor dapat mengecek langsung hasil dokumentasi yang dilakukan perawat pelaksana dan memberikan motivasi untuk melengkapi dokumentasi. Hal ini menunjukan bahwa supervisi yang 
dilakukan dengan baik akan meningkatkan pendokumentasian asuhan keperawatan. Penelitian menyebutkan bahwa ada perbedaan yang bermakna antara kinerja perawat yang disupervisi kepala ruang dilatih dan dibimbing 6 kali dan 3 kali dengan yang disupervisi kepala ruang dilatih tidak dibimbing dengan nilai $p$ value $=0,016$.

Pada jurnal dijelaskan bahwa terdapat peningkatan kelengkapan dokumentasi setelah dilakukan supervisi klinik. Sejumlah 26 dokumentasi asuhan keperawatan tidak lengkap sebelum dilakukan supervisi klinik, sedangkan setelah supervisi klinik terdapat 25 dokumentasi asuhan keperawatan dalam kategori lengkap. Kondisi tersebut menunjukkan bahwa terjadi perubahan kelengkapan pengisian dokumentasi asuhan keperawatan setelah dilakukan supervisi. Kondisi tersebut sesuai dengan penelitian yang dilakukan oleh Herdiana dan Rosa (2011) yang mendapatkan hasil adanya pengaruh yang bermakna fungsi perencanaan dan pengarahan supervisor keperawatan terhadap dkumentasi asuhan keperawatan. Manajerial supervisi klinik memiliki kontribusi untuk pelaksanaan dokumentasi asuhan keperawatan di RS PKU Muhammadiyah Yogyakarta sebesar $85 \%$. Di dalam penelitian yang dilakukan oleh Diyanto menjelaskan bahwa terdapat beberapa faktor yang dapat berpengaruh terhadap kelengkapan dokumentasi asuhan keperawatan diantaranya adalah perbandingan jumlah perawat dan pasien tidak seimbang, usia perawat, banyak dokter yang melengkapi dokumen catatan medis, model pengisian asuhan keperawatan yang terlalu panjang sehingga menyita waktu perawat untuk mengisinya. Wirawan, Novitasari dan Fiki Wijayanti (2013) juga menegaskan bahwa terdapat hubungan spervisi kepala ruang terhadap proses pendokumentasian asuhan keperawatan di Rumah Sakit Umum Daerah Ambarawa. Wirawan, Novitasari, dan Fiki menjelaskan bahwa faktor kelengkapan dokumentasi dipengaruhi oleh faktor internal dan eksternal. Faktor internal yakni meliputi sikap perawat, dan kebiasaan. Sedangkan faktor eksternal diantaranya jumlah peralatan/ sarana, perbandingan tenaga perawat dan pasien. Adanya faktor internal dan eksternal yang mempengaruhi proses dokumentasi menunjukkan bahwa perlu adanya bimbingan dan pengawasan proses dokumentasi dalam bentuk supervisi klinik.

2) Meningkatkan kepatuhan cuci tangan five moment

Berbagai penelitian dankonsep teori di temukan berbagai faktor yangmempengaruhi pelaksanaan cuci tangan limamomen antara lain adalah supervisi ataupengawasan, pengetahuan, pendidikan,kepemimpinan, fasilitas atau infrastruktur,motivasi, pengalaman dan pelatihan(Kurniadi, 2013). Terdapat perbedaan yang bermakna pelaksanaan cucitangan lima momen sebelum dan sesudahditerapkan supervisi klinik Rumah Sakit diBojonegoro $(\mathrm{p}=0.000, \mathrm{p}<0.05)$. Hal ini menunjukkan bahwa pelaksanaan supervisi klinik kepala ruang akan meningkatkanpelaksanaan cuci tangan lima momen.Supervisi dalam keperawatan merupakansuatu proses pemberian sumbersumber yangdibutuhkan perawat untuk menyelesaikantugas dalam rangka pencapain tujuan yangtelah ditetapkan. Melalui supervisi memungkinkan seorang manajer keperawatandapat menemukan berbagai kendala yangdihadapi dalam pelaksanaan asuhankeperawatan diruang yang bersangkutanmelalui analisis secara komprehensif.

Beberapa hasilpenelitian menyatakan supervisi akanmeningkatkan kinerja perawat, supervisi mempengaruhi kepuasan perawat pelaksana,supervisi meningkatkan kualitas perawatanluka, supervisi meningkatkan perilaku keselamatan perawat, supervisi meningkatkanpelaksanaan program, supervisi meningkatkanpelaksanaan pemberian cairan intravena, dansupervisi akanmeningkatkan perilaku caring(Lilian, 
2011; Tampilang, 2013; Widiyanto,2012; Yulita, 2012; Akiyah, 2012; Kenny \&Allenby, 2012).

3) Faktor eksternal

Faktor internal merupakan faktor yang mempengaruhi kinerja perawat yang dapat berasal dari luar individu tersebut meliputi peraturan ketenagakerjaan, keinginan pelanggan, pesaing, kondisi ekonomi, kebijakan organisasi, kepemimpinan, tindakan rekan kerja, jenis latihan dan pengawasan, reward, dan lingkungan sosial.

1) Menurunkan burnout

Hasil yang didapatkan bahwa supervisi dapat menurunkan burnout. Supervisi dapat membantu perawat memahami dirinya dengan baik, emosi, dan aspek kebiasaan. Pengukuran dilakukan sebelum dan setelah supervisi menggunakan human services survey varian yang ditranslate di Latvian. Setiap partisipan mengisi kuesioner survey dan kepuasan setelah mengikuti supervisi.

2) Meningkatkan lingkungan kerja

Lingkungan kerja perlu diperhatikan dalam sistem manajemen di suatu intansi, walaupun lingkungan kerja tidak menjadi sebuah proses produksi dari instansi tersebut, namun lingkungan kerja mempunya pengaruh terhadap hasil produksi tersebut. Karena tentunya lingkungan kerja akan bersinggungan dengan para karyawan instansi yang menjadi pelaksana produksi untuk mencapai hasil produksi bila lingkungan kerja tidak nyaman maka akan mempenguhi karyawan. Penelitian juga menunjukkan bahwa terdapat pengaruh antara lingkungan kerja perawat dengan pelaksanaan praktek keperawatan (O'Connell, Bev; Cherene M. Ockerby; Susan Johnson; Helen Smenda; Tracey K. Bucknall. 2015).

Secara definisi lingkungan kerja merupakan sesuatu yang ada di lingkungan para pekerja yang dapat mempengaruhi dirinya dalam menjalankan tugas seperti temperatur, kelembapan, ventilasi, penerangan, kegaduhan, kebersihan tempat kerja dan memadai tidaknya alat-alat perlengkapan kerja. Adapun pengertian menurut Simanjuntak (2003) menjelaskan bahwa lingkungan kerja merupakan keseluruhan alat perkakas yang dihadapi, lingkungan sekitarnya dimana seorang bekerja, metode kerjanya, sebagai pengaruh kerjanya baik sebagai perorangan maupun sebagai kelompok.

Salah satu yang dapat mempengaruhi lingkungan kerja yang adaptif perlu adanya supervisi klinik. Hal ini di dukung dengan penelitian (Bev O'Connell, Cherene M. Ockerby, Susan Johnson, Helen Smenda, and Tracey K. Bucknall, 2015) yang menyatakan bahwa ada pengaruh Tim Supervisi klinik terhadap meningkatkan lingkungan kerja yang lebih sehat dengan hasil yang positif bagi staf individu, tim bangsal, pasien dan organisasi pelayanan kesehatan. Ini juga didukung oleh penelitian Abdul Ghofar (2010) bahwa lingkungan kerja dapat mempengaruhi kepuasan kerja dan kinerja perawat.

3) Menurunkan resiko jatuh

Penerapan supervisi klinik memberikan pengaruh pada berbagai aspek, salah satunya pada penurunan resiko jatuh. Pada penelitian yang dilakukan oleh Sandra Cruz et al dalam jurnalnya yang berjudul improving evaluation of risk of fall through clinical supervision: an evidence bahwa resiko jatuh dapat dimonitor menggunakan instrumen morse fall scale. Serta dengan adanya supervisi klinik, terjadi peningkatan dalam pengkajian dan monitoring resiko jatuh oleh perawat. Setelah pelaksanaan model supervisi klinik pada perawat, ditemukan adanya banyak intervensi keperawatan yang cocok untuk mengidentifikasi resiko jatuh (Cruz, 2016).

\section{Simpulan dan Saran}

Supervisi adalah kegiatan keterampilan yang disadari dan disengaja bahwa penggunaan intervensi diperlukan sehingga tujuan, kualitas refleksi dan pembelajaran terjadi. Hasil review dari beberapa jurnal menunjukkan supervisi 
klinik yang dilakukan di rumah sakit memiliki dampak positif bagi kegiatan yang dilakukan di rumah sakit. Dampak tersebut antara lain dapat meningkatkan dokumentasi asuhan keperawatan, sebelum dilakukan supervisi klinik terdapat $25,7 \%$ dokumentasi asuhan keperawatan yang lengkap, setelah dilakukan supervisi terjadi peningkatan menjadi $71,4 \%$, meningkat sebesar 45,7\%.

Kepatuhan pelaksanaan hand higiene five moment sebelum supervisi 43,5\%, setelah dilakukan supervisi klinik meningkat menjadi $83,9 \%$, terjadi peningkatan sebesar 40,4\%. Kinerja perawat setelah dilakukan supervisi klinik mengalami peningkatan sebesar $23,75 \%$. Ada perbedaan signifikan dalam pengelolaan emosi sehingga membantu menurunkan Burnout perawat dengan membantu perawat memahami dirinya dengan baik, emosi, dan aspek kebiasaan. Supervisi klinik meningkatkan kualitas lingkungan kerja yang lebih sehat dengan hasil yang positif bagi staf individu, tim bangsal, pasien dan organisasi pelayanan kesehatan perawat.

Supervisi klinik meningkatkan pengkajian dan monitoring resiko jatuh. Supervisi klinik meningkatkan kualitas pelayanan keperawatan khususnya dalam hal pemberian pengobatan menggunakan obat - obatan resiko tinggi (heparin, warfarin, norepinephrine, dobutamin, dan dopamin).

\section{Daftar Pustaka}

Abdul Ghofar. 2010. Pengaruh Lingkungan Kerja terhadap Kinerja Perawat Melalui Kepuasan Sebagai Variabel Intervening. Jurnal Ilmiah Mahasiswa FEB. Unisma Malang

Buus, Niels; Lisa Lynch; Henrik Gonge. 2016. Developing and Implementing 'Meta-Supervision' for Mental Health Nursing Staff Supervisees: Opportunities and Challenges. The Cognitive Behaviour Therapist vol. 9, e22, page 1 of 15
Circenis, Kristaps; Jekaterina Jeremejeca; Inga Millere; Liana Deklaca; Artuts Paparde; Velga Sudraba. 2015. Supervision in Nursing L Latvian Sample Study. p. 86-91.

Cross, W. Moore, A \& Ockerby, S. 2010. Clinical Supervision Of General Nurses In A Busy Medical Ward Of A Teaching Hospital. Contemporary Nurse: A Journal For The Australian Nursing Profession. 35(2), 245-253. doi: $10.5172 /$ conu.2010.352.245

Cruz, Sandra; Antonio; Luis Carvalho; Paulino Sousa.2015. Clinical Supervision and Emotional Intelligence Capabilities: EExcellence in Clinical Practice. Vol171, p. 153-157. Social and behavioral csiences. Sciendirect

Cruz, Sandra; Luís Carvalho; Elsa Lopes. 2016. Improving The Evaluation of Risk of Fall Through Clinical Supervision: An Evidence. Procedia - Social and Behavioral Sciences Vol. 217p. 382-388

Esfahani, Asghar Khalifehzadeh, Fatemeh Ramezany Varzaneh, Tahereh Changiz. 2017.The Effect of Clinical Supervision Model on High AlertMedication Safety in Intensive Care Units Nurses. p.482-486.

Herdiana \& Rosa. (2011). Pengaruh Fungsi Manajerial Supervisi Klinik Terhadap Dokumentasi Asuhan Keperawatan Di RS Pku Muhammadiyah Yogyakarta. Bagian Magister Manajemen Rumah Sakit Universitas Muhammadiyah Yogyakarta

Kurniadi, Anwar. (2013). Manajemen Keperawatan dan Prospektifnya: Teori dan Aplikasi. Jakarta: Fakultas Kedokteran Universitas Indonesia. 
Lestari, Nunik Wahyu; Erni Suprapti; Achmad Solechan. 2014. Pengaruh Supervisi Klinik Terhadap Kelengkapan Dokumentasi Asuhan Keperawatan Di RSUD H. Soewondo Kendal.

Rahayu, Lucia Maria Tri. 2004. Pengaruh supervisi klinik terhadap kompetensi perawat di Rawat Inap Rumahsakit St. Elisabeth Semarang. Yogyakarta: Universitas Gadjah Mada.

Mandagi, Umboh, dan Ratu. (2015). Faktor-faktor yang Berhubungan dengan Kinerja Perawat dalam menerapkan Asuhan Keperawatan di Rumah Sakit Umum Bethesda GMIM Tomohon. Jurnal e-Biomedik (eBm). Vol 3, no.3, hal 844-894

Mustikaningsih, Dewi. 2014. Pengaruh Supervisi Klinik Ketua Tim Model 4S Terhadap Kinerja Perawat Pelaksana Dalam Metode Asuhan Keperawatan Tim. Jurnal Keperawatan Aisyiyah (JKA). Vol 1, No 1.

O'Connell, Bev; Cherene M. Ockerby; Susan Johnson; Helen Smenda; Tracey K. Bucknall. 2015. Team ClinicalSupervision in AcuteHospital Wards:A Feasibility Study

Ponco, S. Hananto; Virgianti Nur Faridah. 2016. Penerapan Supervisi Klinik Kepala Ruang Untuk Meningkatkan Pelaksanaan Cuci Tangan Lima Momen Perawat Pelaksana RSUD Bojonegoro

Saleh, N.EL-shawadfy; Wafaa Fathi Sleem;Ahlam Mahmoud EL-Shaer. 2015. Effect of Clinical Supervision Program for Head Nurses on Quality Nursing Care.Vol 4, Issue 6 Ver. V.

Siahaan, D. Natalia \& Mula Tarigan. 2012. Kinerja Perawat Dalam Pemberian Asuhan Keperawatan Di Rumah Sakit Tk Ii Putri Hijau Medan.
Simanjuntak, Payaman J, 2003, Produktivitas Kerja Pengertian dan Ruang Lingkupnya, Prisma, Jakarta.

Tika, Mohammad Pabundu. 2006. Budaya Organisasi Dan Peningkatan Kinerja Perusahaan. Jakarta: Bumi Aksara.

Wirawan, Novitasari, Wiajayanti. (2013). Hubungan Antara Supervisi Kepala Ruang dengan Pendokumentasioan Asuhan Keperawatan di Rumah Sakit Umum Daerah Ambarawa. Jurnal Manajemen keperawatan. Vol.1, no.1, hal 1-6

Wiyana, Muncul. (2008). Supervisi dalam Keperawatan. Diambil pada tanggal 10 November 2017. Dari http://www.akpermadiun.ac.id/index. php?link=artikeldtl.php\&id=3

Yanti, R. Ida \& Bambang Edi Warsito. 2013. Hubungan Karakteristik Perawat, Motivasi, Dan Supervisi Dengan Kualitas Dokumentasi Proses Asuhan Keperawatan. Jurnal Managemen Keperawatan . Vol. 1, No. 2. 107-114

Zahara, Sitorus, Sabri. (2011). FaktorFaktor Motivasi Kerja : Supervisi, Penghasilan, dan Hubungan Interpersonal Memengaruhi Kinerja erawat Pelaksana. Jurnal Keperawatan Indonesia, vol 14 No. 2. Hal 73-82 